\title{
EFFECTS OF ISCHEMIC AND PROTON PUMP INHIBITORS PRECONDITIONING ON OXIDATIVE STRESS OF ISOLATED RAT HEART
}

Nevena Jeremic ${ }^{1}$, Vladimir Zivkovic ${ }^{2}$, Ivan Srejovic ${ }^{2}$, Jovana Jeremic ${ }^{3}$, Anica Petkovic ${ }^{3}$, Jovana Bradic ${ }^{3}$, Vladimir Jakovljevic ${ }^{2,4}$

${ }^{1}$ Department of Pharmaceutical chemistry, Faculty of Medical Sciences, University of Kragujevac, Kragujevac, Serbia ${ }^{2}$ Department of Physiology, Faculty of Medical Sciences, University of Kragujevac, Kragujevac, Serbia ${ }^{3}$ Department of Pharmacy, Faculty of Medical Sciences, University of Kragujevac, Kragujevac, Serbia ${ }^{4}$ Department of Human Pathology, 1st Moscow State Medical University IM Sechenov, Moscow, Russia

\section{EFEITI ISHEMIJSKO G I PREIKONDICIONIRANJA INHIBITORIMA PROTONSKE PUMPE NA OISIDACIONI STRES IZOLOVANOG SRCA PACOVA

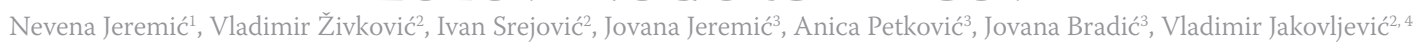 \\ ${ }^{1}$ Katedra za farmaceutsku hemiju, Fakultet medicinskih nauka, Univerzitet u Kragujevcu, Kragujevac, Srbija \\ ${ }^{2}$ Katedra za fiziologiju, Fakultet medicinskih nauka, Univerzitet u Kragujevcu, Kragujevac, Srbija \\ ${ }^{3}$ Katedra za farmaciju, Fakultet medicinskih nauka, Univerzitet u Kragujevcu, Kragujevac, Srbija \\ ${ }^{4}$ Odsek za humanu patologiju, Prvi Moskovski državni medicinski univerzitet I.M. Sechenov, Moskva, Rusija}

Received / Primljen: 11. 03. 2017.

Accepted / Prihvaćen: 14. 03. 2017.

\begin{abstract}
Aim of present study was to determine the participation of various biomarkers of oxidative damage: nitrite $\left(\mathrm{NO}_{2}{ }^{-}\right)$, superoxide anion radicals $\left(\mathrm{O}_{2}^{-}\right)$, index of lipid peroxidation (TBARS) and hydrogen peroxide $\left(\mathrm{H}_{2} \mathrm{O}_{2}\right)$ in coronary circulation after application of the different models of preconditioning such as ischemic and preconditioning with proton pump inhibitors.

Examining a biochemical markers of oxidative damage we did not notice any increased production values of any parameter, according to that we can hypothesize that possible occurrence of reperfusion injury after ischemia and PPIs preconditioning is not mediated by this mechanism.

Due to the very difficult and controversial application of ischemic preconditioning in clinical practice, the results of this study suggest that in the future proton pump inhibitors can contribute to the prevention of myocardial damage following ischemia
\end{abstract}

Keywords: ischemic preconditioning, myocardial infarction, proton pump inhibitors, oxidative stress

\section{SAŽETAK}

Cilj ove studije bio je ispitati učesće različitih biomarkera oksidacionog oštećenja : nitrita $\left(\mathrm{NO}_{2}^{-}\right)$, superoksid anjon radikala $\left(\mathrm{O}_{2}^{-}\right)$, lipidnih peroksida (TBARS) i vodonik peroksida $\left(\mathrm{H}_{2} \mathrm{O}_{2}\right)$ pri primeni različitih vrsta prekondiconiranja kao sto su prekondicioniranje ishemijom i prekondicioniranje lekovima iz grupe inhibitora protonske pumpe.

$S$ obzirom da ispitujući biohemijske markere oksidacionog oštećenja nismo uočili da je došlo do pojačane produkcije vrednosti bilo kog parametra, možemo pretpostaviti da eventualni nastanak reperfuzione povrede nakon prekondicioniranja ishemijom i lekovima iz grupe inhibitora protonske pumpe nije posredovan ovim mehanizmom.

Zbog veoma teške $i$ kontroverzne primene ishemijskog prekondicioniranja u kliničkoj praksi, rezultati ove studije sugerišu da u budućnosti lekovi iz grupe inhibitora protonske pumpe mogu imati svoj doprinos u prevenciji oštećenja miokarda nakon ishemije.

Ključne reči: ishemijsko prekondicioniranje, infarkt miokarda, inhibitori protonske pumpe, oksidacioni stres

\section{INTRODUCTION}

There is no doubt that myocardial ischemia (MI) is one of the major causes of morbidity and mortality worldwide. Various medical and surgical strategies have been developed over the years in order to minimize the deep and devastating effects on metabolism and myocardial contractility as well as the sustainability of myocytes due to acute myocardial infarction (AMI). Approaches vary, but usually include the use of thrombolytic agents, antagonist $\beta$-adrenergic receptor, inhibitors of angiotensin converting enzyme (ACE), the use of antioxidants, the use of transluminal coronary angioplasty, coronary artery bypass grafting. One of the few interventions that are universally accepted and still causes a great deal of attention by the scientific world is certainly a phenomenon of heart ischemia preconditioning (1).

Over time, a growing number of studies observed different models and effects of preconditioning $(2,3)$. Preconditioning stimulus itself leads to the start of the whole cascade of endogenous adaptive mechanisms that ultimately result in the development of tolerance. It was also shown that preconditioning is powerful mechanism that protects the myocardium from ischemic damage, to reduce the occurrence of arrhythmia, and that has a role in maintaining contractility of the cardiac muscle (4). 
The mechanism of the formation of reactive oxygen species (reactive oxygen spieces - ROS) is very important in the process of reperfusion injury and experimental studies have shown that reperfusion after ischemia generates oxidative stress, which can then be intermediary for myocardial infarction. The oxygen that reaches infarction who had previously suffered ischemia, leads to the formation of free radicals, primarily superoxide, hydroxyl radicals, peroxynitrite, which just in the first few minutes of establishing blood flow leads to the development of reperfusion injury. ROS can occur as a result of the activation, and neutrophil accumulation during reperfusion resulting in the release of platelet activating factor derived from the endothelium, which attract neutrophils and enhance the production of ROS as well as the degree of reperfusion injury. During reperfusion, oxidative stress has also reduces the bioavailability of intracellular signaling molecules such as nitric oxide, thereby negating its cardio protection $(5,6)$.

Since the goal of any kind of preconditioning is to reduce infarct size, the available literature data that can be found today used a wide variety of pharmacological agents, among them also proton pump inhibitors (PPI).

Gomes and his associates in its two research looked at the role of omeprazole and pantoprazole as possible preconditioning agents. In a study with omeprazole is observed that the drug significantly contribute to a recovery in isolated rat heart after injury caused by myocardial ischemia and reperfusion. Similar conclusions are performed from a survey conducted with pantoprazole on isolated rat heart and same findings we have from our previous work (7-9).

According to all previous our aim was to determine the participation of various biomarkers of oxidative damage: nitrite $\left(\mathrm{NO}_{2}^{-}\right)$, superoxide anion radicals $\left(\mathrm{O}_{2}^{-}\right)$, index of lipid peroxidation (TBARS) and hydrogen peroxide $\left(\mathrm{H}_{2} \mathrm{O}_{2}\right)$ in coronary circulation after application of the different models of preconditioning such as ischemic and preconditioning with proton pump inhibitors.

\section{MATERIAL AND METHODS}

\section{Preparation of isolated rat hearts}

The hearts of male Wistar albino rats $(\mathrm{n}=36,12$ in each experimental group, body mass 180-200 g) were excised and perfused on a Langendorff apparatus (Experimetria Ltd,1062 Budapest, Hungary). After a short-term ketamine/xylasin narcosis, animals were killed by cervical dislocation (Schedule 1 of the Animals/ Scientific Procedures, Act 1986, UK), and premedicated with heparin as an anticoagulant. After emergency thoracotomy and rapid cardiac arrest by superfusion with ice-cold isotonic saline, rapidly excised, the aortas were cannulated and retrogradely perfused under a constant perfusion pressure (CPP). The composition of the non-recirculating Krebs-Henseleit perfusate was as follows $(\mathrm{mM}): \mathrm{NaCl} 118, \mathrm{KCI} 4.7, \mathrm{CaCI}_{2}$ $x 2 \mathrm{H}_{2} \mathrm{O} 2.5, \mathrm{MgSO}_{4} x 7 \mathrm{H}_{2} \mathrm{O} 1.7, \mathrm{NaHCO}_{3} 25, \mathrm{KH}_{2} \mathrm{PO}_{4} 1.2$, glucose 11 , pyruvate 2, equilibrated with $95 \% \mathrm{O}_{2}$ plus $5 \%$ $\mathrm{CO}_{2}$ and warmed to $37^{\circ} \mathrm{C}$ ( $\mathrm{pH}$ 7.4). Immediately after the restoration of normal heart rhythm, through the created entrance to the left atrium of the heart and damaged mitral valve, the sensor (transducer BS473-0184, Experimetria Ltd, Budapest, Hungary) was inserted into the left ventricle for continuous monitoring of cardiac function.

\section{Physiological assay and experimental protocol}

All study groups underwent 30 min perfusion at $\mathrm{CPP}$ of $70 \mathrm{~cm} \mathrm{H}_{2} \mathrm{O}$. In control group (CG) after stabilization period, hearts were subjected to global ischemia (perfusion was totally stopped) for 20 minutes and 30 minutes of reperfusion (Protocol 1). Hearts of group II (IPC) were submitted to ischemic preconditioning lasting 2 minutes of ischemia and 4 minutes of reperfusion before global ischemia of 20 minutes and 30 minutes of reperfusion (Protocol 2). Third, fourth and fifth groups were groups with pharmacological preconditioning (proton pump inhibitors). All of these groups first underwent preconditioning lasting 5 minutes with $100 \mu \mathrm{M}$ of drug (omeprazole, pantoprazole and lansoprazole) then submitted 20 minutes of ischemia and 30 minutes of reperfusion (Protocol 3).

In control group, coronary venous effluent was collected in point of stabilization (S), in first point of reperfusion (R1) and on every 5 minutes in period of reperfusion (R1-R7). In group with ischemic preconditioning coronary venous effluent was collected in point of stabilization (S), in each point on every minute of 4 minute reperfusion period (RP1-RP4) and from first to the last point of 30 minutes reperfusion period on every 5 minutes (R1-R7). In groups of pharmacological preconditioning coronary venous effluent was collected in point of stabilization (S) and from first to the last point of 30 minutes reperfusion period on every 5 minutes (R1-R7).

\section{Drugs}

All drugs were purchased from Sigma-Aldrich Chemie GmbH, Germany.

\section{Biochemical Assays}

In the collected samples of coronary venous effluent, following markers of oxidative stress were measured spectrophotometrically: (1) index of lipid peroxidation (measured as TBARS - thiobarbituric acid reactive substances); (2) nitrites $\left(\mathrm{NO}_{2}^{-}\right)$; (3) hydrogen peroxide $\left(\mathrm{H}_{2} \mathrm{O}_{2}\right)$; (4) superoxide anion radical $\left(\mathrm{O}_{2}^{-}\right)$.

\section{Index of lipid peroxidation}

The degree of lipid peroxidation in the coronary venous effluent was estimated by measuring TBARS using $1 \%$ thiobarbituric acid (TBA) in $0.05 \mathrm{NaOH}$ incubated with the coronary effluent at $100{ }^{\circ} \mathrm{C}$ for $15 \mathrm{~min}$ and read at $530 \mathrm{~nm}$. Krebs-Henseleit solution was used as a blank probe (10). 
Nitrite determination

NO rapidly decomposes to form stable metabolite nitrite/ nitrate products. The nitrite $\left(\mathrm{NO}_{2}^{-}\right)$level was measured as an index of NO production using the Griess reagent. A total of $0.5 \mathrm{ml}$ of perfusate was precipitated with $200 \mu \mathrm{l}$ of $30 \%$ sulphosalicylic acid, vortexed for $30 \mathrm{~min}$, and centrifuged at $3000 \times g$. Equal volumes of the supernatant and Griess reagent, containing $1 \%$ sulphanilamide in $5 \%$ phosphoric acid $/ 0.1 \%$ naphthalene ethylenediamine dihydrochloride, were added, incubated for $10 \mathrm{~min}$ in the dark, and read at $543 \mathrm{~nm}$. The nitrite levels were calculated using sodium nitrite as the standard (11).

\section{Determination of superoxide anion radical}

The level of the superoxide anion radical $\left(\mathrm{O}_{2}^{-}\right)$was measured by nitro blue tetrazolium (NBT) reaction in Tris buffer with coronary venous effluent and read at $530 \mathrm{~nm}$. Krebs-Henseleit solution was used as a blank probe (12).

\section{Determination of hydrogen peroxide}

The measurement of $\mathrm{H}_{2} \mathrm{O}_{2}$ is based on the oxidation of phenol red by $\mathrm{H}_{2} \mathrm{O}_{2}$ in a reaction catalyzed by horseradish peroxidase (HRPO) (13). A volume of 2001 of perfusate was precipitated with 8001 of fresh phenol red solution (PRS), along with 101 of 1:20 HRPO (made ex tempore). An adequate volume of Krebs-Henseleit solution was used for a blank probe (instead of coronary venous effluent). The level of $\mathrm{H}_{2} \mathrm{O}_{2}$ was measured at $610 \mathrm{~nm}$.

\section{Statistical analysis}

For statistical analysis we examined three measured points, first point was stabilization (S), second was the first and the last point of 30 minutes reperfusion period (R1 and R7). Values are expressed as mean \pm SE. Statistical analysis

Table 1. Statistical significance and results for all observed groups

\begin{tabular}{|c|c|c|c|c|c|}
\hline \multicolumn{5}{|c|}{ Index of lipid peroxidation (TBARS) } \\
\hline $\begin{array}{c}\text { Points of } \\
\text { interest/ } \\
\text { Groups }\end{array}$ & Control & IP & OP & LP & PP \\
\hline S vs R1 & $P<0.05^{*}$ & $P>0.05$ & $P>0.05$ & $P>0.05$ & $P>0.05$ \\
\hline S vs R7 & $P<0.05^{*}$ & $P>0.05$ & $P<0.05^{*}$ & $P<0.01^{* * * *}$ & $P>0.05$ \\
\hline R1 vs R7 & $P<0.01^{* *}$ & $P>0.05$ & $P>0.05$ & $P>0.05$ & $P<0.05^{*}$ \\
\hline $\begin{array}{c}\text { Decrease } \\
(-) \text { or in- } \\
\text { crease (+) } \\
\text { values R7 } \\
\text { vs } \text { R1 (\%) }\end{array}$ & $-43,92$ & $-37,26$ & $-58,98$ & $-23,28$ & $-27,83$ \\
\hline $\begin{array}{c}\text { Decrease } \\
(-) \text { or in- } \\
\text { crease (+) } \\
\text { values R7 } \\
\text { vs S (\%) }\end{array}$ & $-25,16$ & $-15,80$ & $-55,66$ & $-25,17$ & $-19,81$ \\
\hline
\end{tabular}

was performed by ANOVA test. P values lower than 0.05 were considered to be significant.

\section{Ethical Approval}

The experimental protocol was approved by the Faculty of Medical Sciences Ethics Committee for the welfare of experimental animals, University of Kragujevac, number 01-12149 and by Ministry of Agriculture, Forestry and Water Management, Authority for Veterinary of Serbia number 323-07-09426/2013-05.

\section{RESULTS}

Effects of ischemic and PPI preconditioning on index of lipid peroxidation

Control group and group with pantoprazole leaded to statistically significant difference between first and last point of reperfusion. Although in all other groups we noticed decreased levels of TBARS in reperfusion period that results were not statistically significant. Except in group were we applied lansoprazole, there were no difference between values in point of stabilization compared to last point of reperfusion (Table 1 and Figure 1).

\section{Effects of ischemic and PPI preconditioning on nitrites}

In all experimental groups we found decreased levels of nitrites in reperfusion period. However in control and group with lansoprazole there were no difference among values in first and last point of reperfusion. When we compared values in S point with values in R7 point we notice that there were no statistical difference between these points in control group and in groups with ischemic and lansoprazole preconditioning (Table 2, Figure 2).

Table 2. Statistical significance and results for all observed groups

\begin{tabular}{|c|c|c|c|c|c|}
\hline \multicolumn{5}{|c|}{ Nitrites $\left(\mathrm{NO}_{2}{ }^{-}\right)$} \\
$\begin{array}{c}\text { Points of } \\
\text { interest/ } \\
\text { Groups }\end{array}$ & Control & IP & OP & LP & PP \\
\hline S vs R1 & $P>0.05$ & $P<0.01^{* * * *}$ & $P>0.05$ & $P<0.05^{*}$ & $P<0.01^{* * *}$ \\
\hline S vs R7 & $P>0.05$ & $P>0.05$ & $P<0.01^{* * *}$ & $P<0.05^{* *}$ & $P<0.05^{*}$ \\
\hline R1 vs R7 & $P>0.05$ & $P<0.01^{* * *}$ & $P<0.01^{* * *}$ & $P>0.05$ & $P<0.01^{* * *}$ \\
\hline $\begin{array}{c}\text { Decrease } \\
(-) \text { or in- } \\
\text { crease (+) } \\
\text { values R7 } \\
\text { vs R1 (\%) }\end{array}$ & $-39,79$ & $-33,69$ & $-46,97$ & $-29,86$ & $-28,83$ \\
\hline $\begin{array}{c}\text { Decrease } \\
(-) \text { or in- } \\
\text { crease (+) } \\
\text { values R7 } \\
\text { vs S (\%) }\end{array}$ & $-33,18$ & $-4,99$ & $-34,16$ & $-15,97$ & $-14,79$ \\
\hline
\end{tabular}




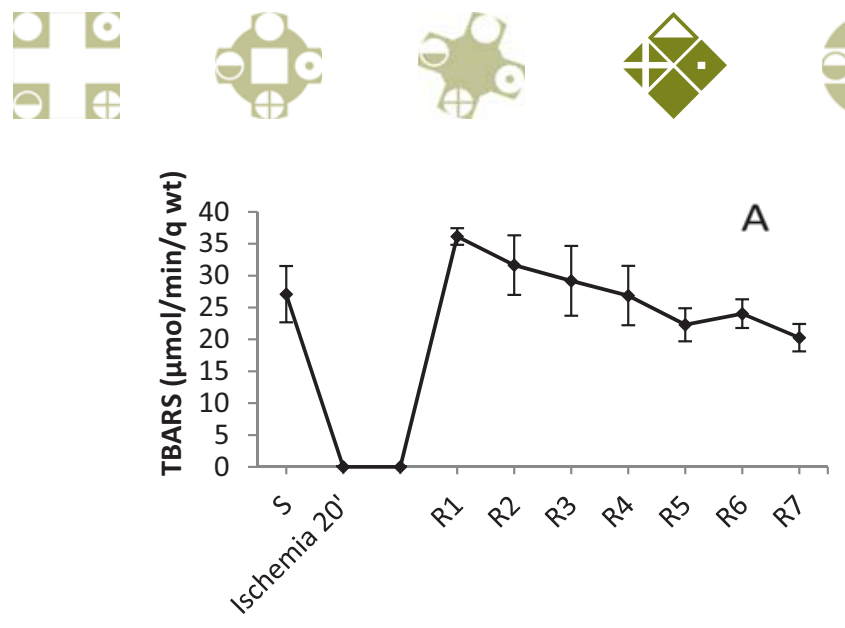

Protocol 1

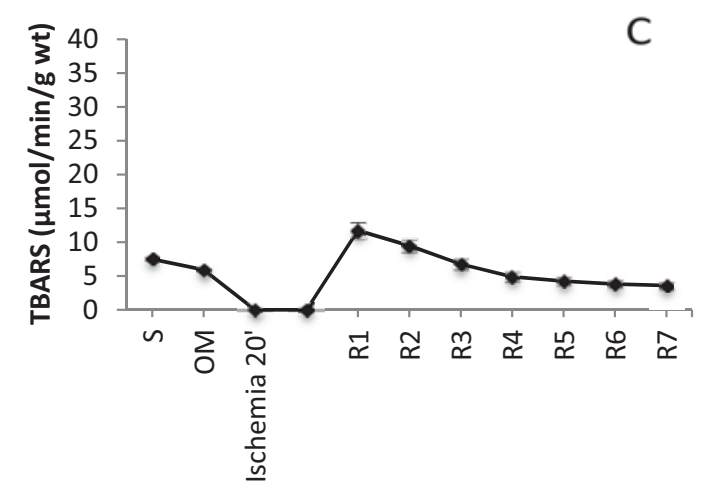

Protocol 3

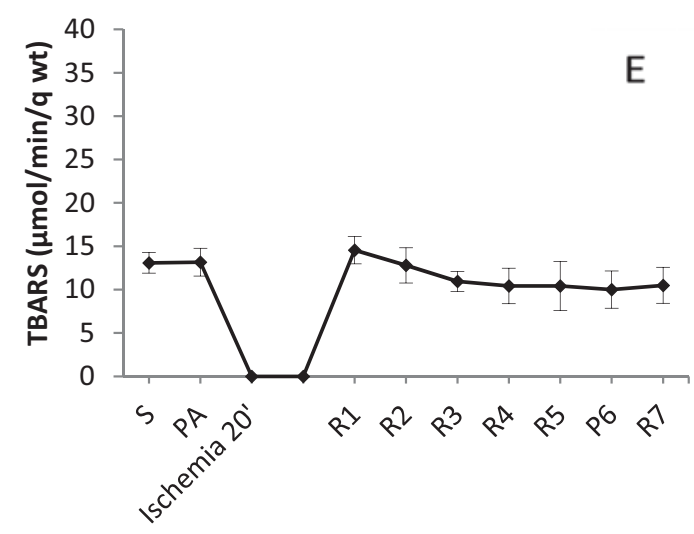

Effects of ischemic and PPI preconditioning on superoxide anion radical

In groups with ischemic and preconditioning with pantoprazole we found statistically significant increase in values of superoxide anion radical in period of reperfusion. Moreover in group with lansoprazole preconditioning in same examined period we showed statistically significant decrease of these values. There were no significant difference between values in $S$ point and values in R7 point in examined groups (Table 3, Figure 3).

\section{Effects of ischemic and PPI preconditioning on hydrogen peroxide}

Ischemic and PPI preconditioning had statistically significant effect on values of hydrogen peroxide in reperfu-

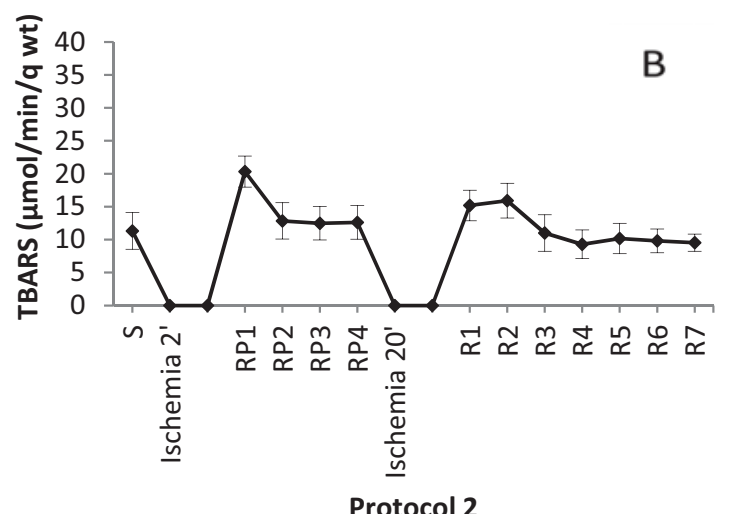

Protocol 2

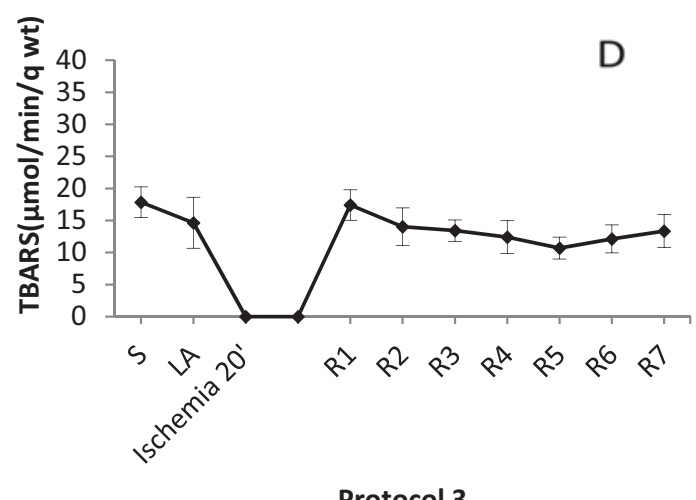

Protocol 3

Figure 1. Figures represent changes in values of index of lipid peroxidation for all observed groups. A: control group, B: group with ischemic preconditioning, C: preconditioning with omeprazole, D: preconditioning with lansoprazole, E: preconditioning with pantoprazole

sion period. In these groups we found decreased values in R7 point compared to R1 point. There were no significant changes in control group. Moreover, in control group, group with ischemic and omeprazole preconditioning we found that there is no difference between values in $S$ point compared to values in $\mathrm{R} 7$ point of examined parameter (Table 4, Figure 4).

\section{DISCUSSION}

Determining the level molecule such as: nitric oxide in the form of nitrite, superoxide anion radicals and hydrogen peroxide and marker of oxidative damage (index of lipid peroxidation) in the coronary venous effluent, we wanted to determine whether ischemic preconditioning and phar- 


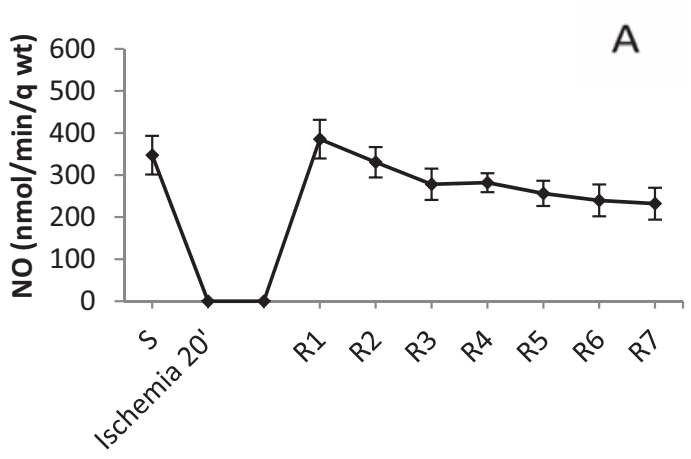

Protocol 1
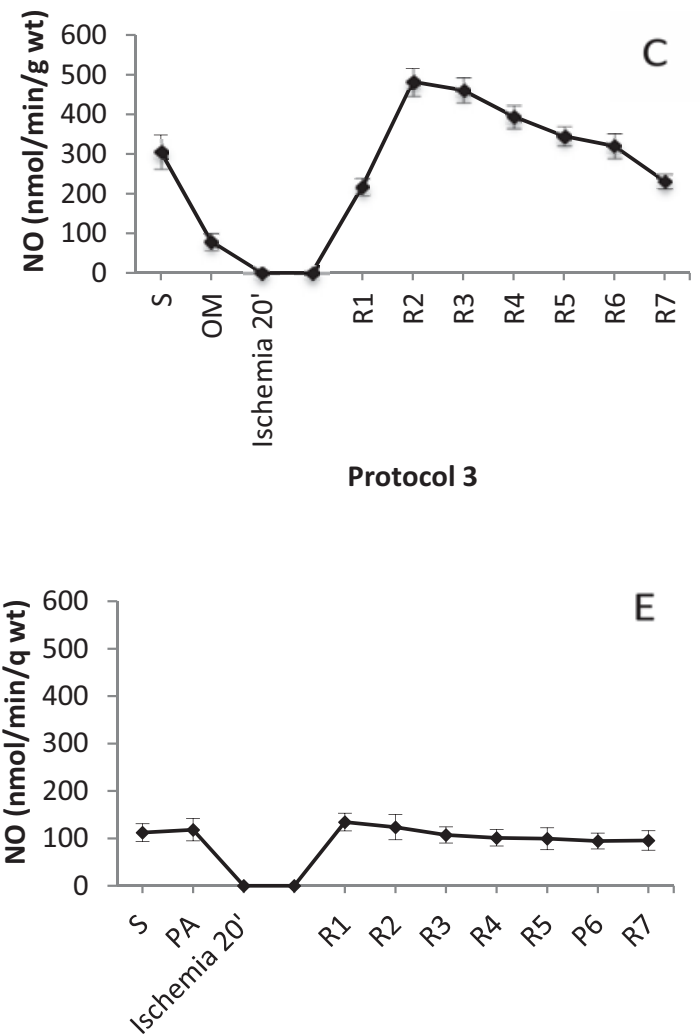

Protocol 3

macological preconditioning with PPIs have a positive or negative effect on the free radical production during reperfusion. Myocardial reperfusion injury is an essential consequence of re-establishing the flow after ischemia. Although the exact mechanisms that can protect the myocardium from the occurrence of the injury or which it can alleviate not yet been adequately investigated, the interest in this problem still remain.

Our results show that drugs called proton pump inhibitors significantly reduced the concentration of nitric oxide in reperfusion period compared to the last point and the point of stabilization, but that is largely decreased of nitrite caused by omeprazole. Control group had decrease in nitrite values for $33.18 \%$ in reperfusion period. The less reduction in the value of exempt nitrite showed the group

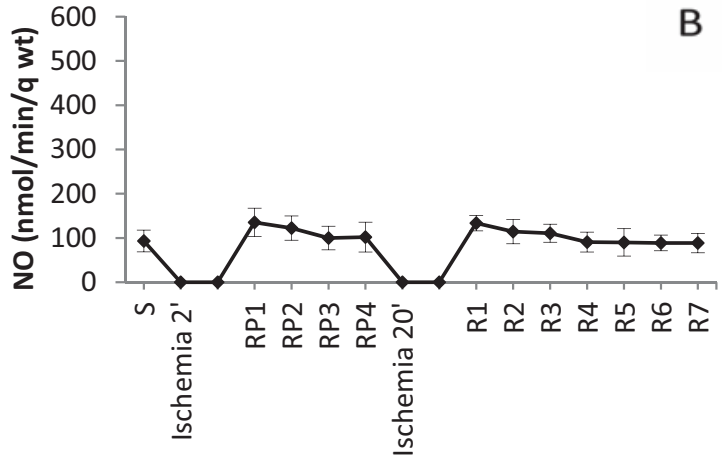

Protocol 2

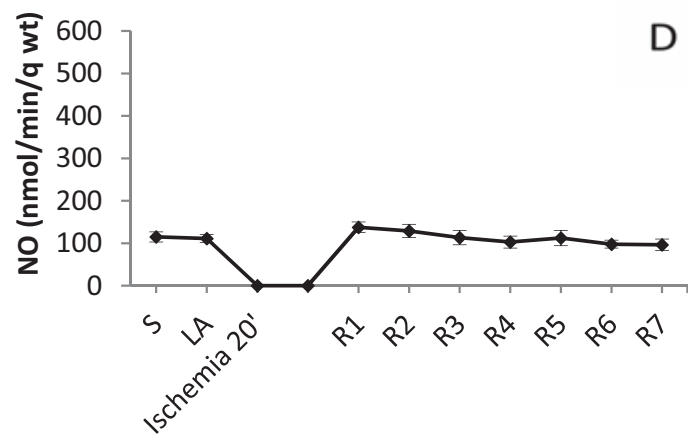

Protocol 3

Figure 2. Figures represent changes in values of nitrites for all observed groups. A: control group, B: group with ischemic preconditioning, C: preconditioning with omeprazole, D: preconditioning with lansoprazole, E: preconditioning with pantoprazole

where myocardium was preconditioned with ischemia (Table 2, Figure 2).

The importance of nitric oxide in the I/R injury of the myocardium is especially great due to its reaction with superoxide anion radical resulting in the generation of peroxynitrite (14-16). Peroxynitrite (ONOO-) can cause oxidation of the protein as well as lipid peroxidation (14). Our results could be interpreted in the light of these facts, because all groups reduced the release of superoxide anion radicals which can be spent on administration to create peroxynitrite by reaction with nitrogen oxide whose values are also in decline.

Review that at the end of the twentieth century posted Nonami et al., indicates that based on a critical review of previously published works, one cannot claim with cer- 


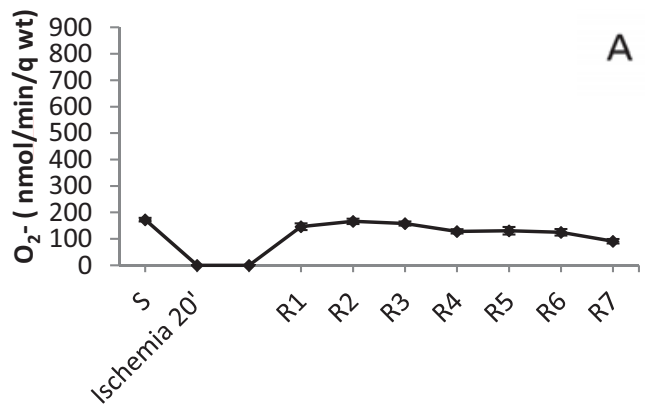

Protocol 1

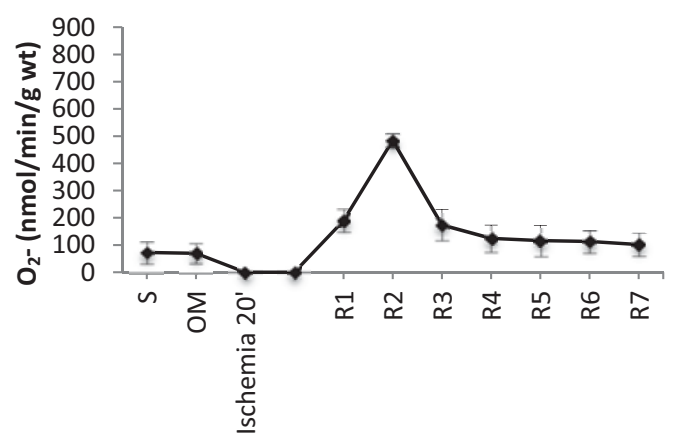

Protocol 3

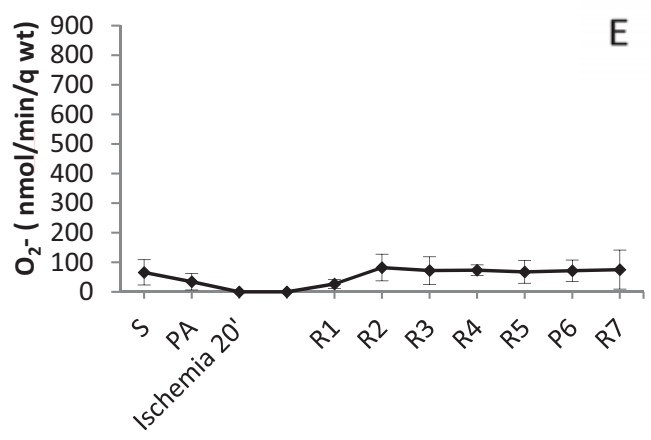

Protocol 3

Table 3. Statistical significance and results for all observed groups

\begin{tabular}{|c|c|c|c|c|c|}
\hline \multicolumn{5}{|c|}{ Superoxide anion radical $\left(\mathrm{O}_{2}{ }^{-}\right)$} \\
\hline $\begin{array}{c}\text { Points of } \\
\text { interest/ } \\
\text { Groups }\end{array}$ & Control & IP & OP & LP & PP \\
\hline S vs R1 & $\mathrm{P}>0.05$ & $\mathrm{P}>0.05$ & $\mathrm{P}>0.05$ & $\mathrm{P}>0.05$ & $\mathrm{P}>0.05$ \\
\hline S vs R7 & $\mathrm{P}>0.05$ & $\mathrm{P}>0.05$ & $\mathrm{P}>0.05$ & $\mathrm{P}>0.05$ & $\mathrm{P}>0.05$ \\
\hline R1 vs R7 & $\mathrm{P}>0.05$ & $\mathrm{P}<0.05^{*}$ & $\mathrm{P}>0.05$ & $\mathbf{P}<0.05^{*}$ & $P<0.05^{*}$ \\
\hline $\begin{array}{c}\text { Decrease (-) } \\
\text { or increase (+) } \\
\text { values R7 vs } \\
\text { R1 (\%) }\end{array}$ & $-37,72$ & $+107,28$ & $-37,73$ & $-56,22$ & $+181,83$ \\
\hline $\begin{array}{c}\text { Decrease (-) } \\
\text { or increase (+) } \\
\text { values R7 vs } \\
\text { S (\%) }\end{array}$ & $-47,30$ & $-39,46$ & $-26,92$ & $-38,57$ & $-13,87$ \\
\hline
\end{tabular}

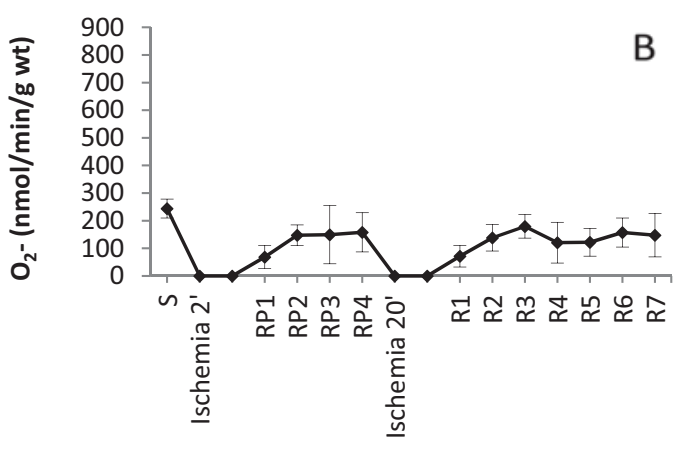

Protocol 2

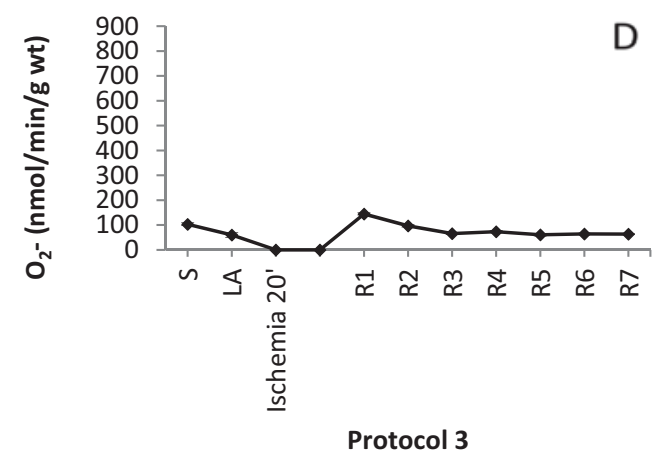

Figure 3. Figures represent changes in values of superoxide anion radical for all observed groups. A: control group, B: group with ischemic preconditioning, C: preconditioning with omeprazole, D: preconditioning with lansoprazole, E: preconditioning with pantoprazole

tainty that neither donors nor precursors of nitric oxide, as well as inhibitors of nitric oxide synthase sufficient to prevent $I / R$ injuries. In conclusion they indicated that nitric oxide may have different effects in terms of myocardial protection and all depending on the time of its application (17).

Although the superoxide anion radical is a highly reactive molecule, in the physiological conditions this molecule almost immediately after the creation has been translated into hydrogen peroxide using mitochondrial (Mn-SOD) and cytosolic (Cu / Zn-SOD), superoxide dismutase. Further, hydrogen peroxide under the action of the enzyme catalase is converted into oxygen and water. However, under certain circumstances, superoxide anion radical can avoid the cascading time, with consequent production of ROS leading to oxidative damage $(14,18,19)$. 


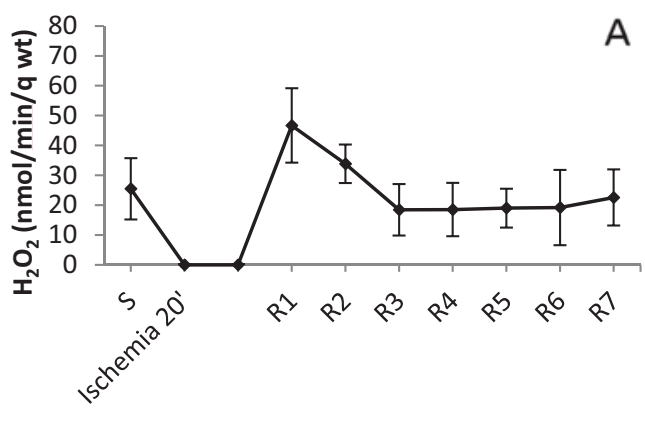

Protocol 1

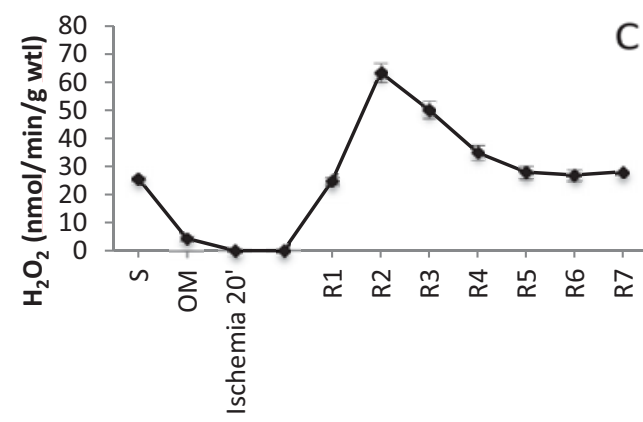

Protocol 3

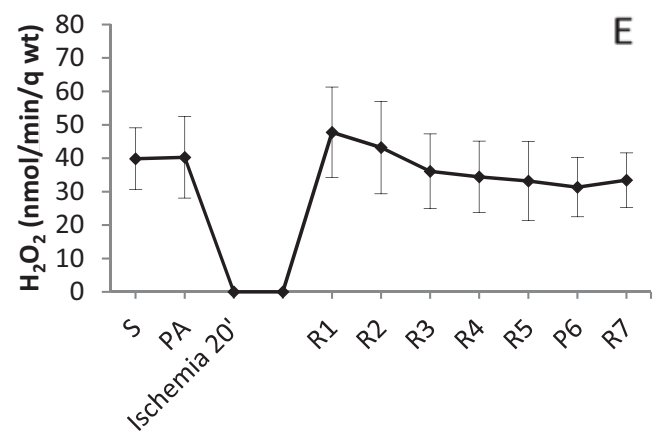

Protocol 3

Table 4. Statistical significance and results for all observed groups

\begin{tabular}{|c|c|c|c|c|c|}
\hline \multicolumn{6}{|c|}{ Hydrogen-peroxide $\left(\mathrm{H}_{2} \mathrm{O}_{2}\right)$} \\
\hline $\begin{array}{c}\text { Points of } \\
\text { interest/ } \\
\text { Groups }\end{array}$ & Control & IP & OP & LP & $\mathbf{P P}$ \\
\hline $\mathrm{S} v s \mathrm{R} 1$ & $P<0.05$ * & $\mathrm{P}>0.05$ & $\mathrm{P}>0.05$ & $P<0.05^{*}$ & $P<0.05^{*}$ \\
\hline $\mathrm{S}$ vs R7 & $P>0.05$ & $P>0.05$ & $\mathrm{P}>0.05$ & $P<0.01$ ** & $P<0.05^{*}$ \\
\hline R1 vs R7 & $\mathrm{P}>0.05$ & $P<0.05 \%$ & $P<0.01^{\text {*** }}$ & $P<0.05^{*}$ & $P<0.01^{\text {** }}$ \\
\hline $\begin{array}{c}\text { Decrease }(-) \\
\text { or increase }(+) \\
\text { values R7 vs } \\
\text { R1 (\%) }\end{array}$ & $-51,65$ & $-37,29$ & $-22,57$ & $-21,27$ & $-30,02$ \\
\hline $\begin{array}{c}\text { Decrease }(-) \\
\text { or increase }(+) \\
\text { values R7 vs } \\
\text { S (\%) }\end{array}$ & $-11,40$ & $-28,56$ & $-26,85$ & $-15,70$ & $-16,10$ \\
\hline
\end{tabular}

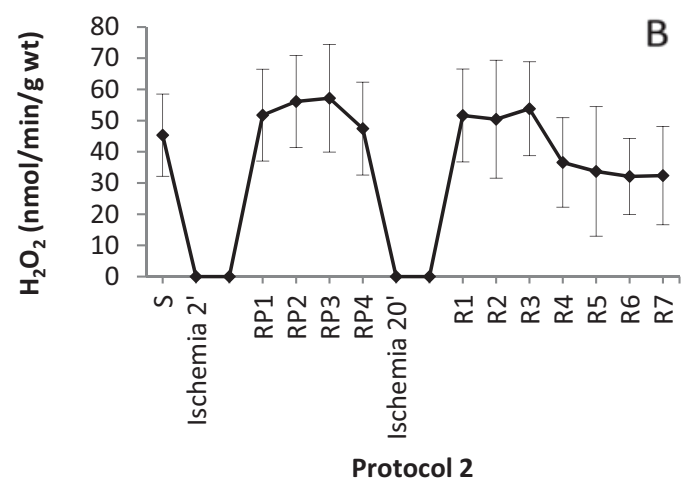

C

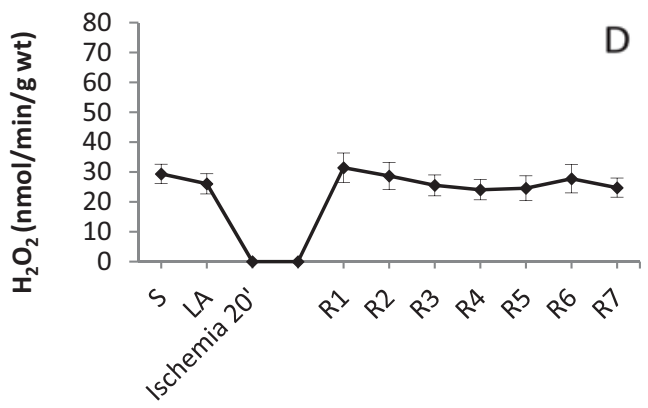

Protocol 3

Figure 4. Figures represent changes in values hydrogen peroxide for all observed groups. A: control group, B: group with ischemic preconditioning, $\mathrm{C}$ : preconditioning with omeprazole, D: preconditioning with lansoprazole, E: preconditioning with pantoprazole

Our results may be seen from the table and graphics (Table 3, Chart 3), indicating reduced release of superoxide anion radical, which is not statistically significant in either study group when comparing the last point of reperfusion and values at point of stabilization. Decrease in superoxide anion radicals by active metabolite of omeprazole showed Wandall early nineties of the last century on the model of isolated polymorphous (20). In a study in isolated rabbit hearts, Omar et al. came to the conclusion that ischemic preconditioning is not mediated by superoxide anion radicals. Research by various laboratories indicated that the generation of ROS plays a vital role in the oxidative damage after ischemia and in the protection of the myocardium. This paradox may be explained by the specific regulatory resources ROS (14).

When it comes to hydrogen peroxide, we saw that after the application of drugs from the group of PPIs percentage drop in values when we compared the point $R 7$ relative to $S$. 
The values of hydrogen peroxide from the coronary venous effluent had the same trend and in the control group or the groups with the ischemic preconditioning (Table 4, Chart 4).

Pantoprazole in a study conducted in an animal model of rats showing its anti-oxidant and cytoprotective effects $(21,22)$. Same ability lansoprazole showed also (23). As far as preconditioning with ischemia, Gozal et al. on the model of the dog heart have shown that this type of prevention of myocardium injury leads to a reduction in the concentration of hydroxyl radicals, and thus concluded that ischemic preconditioning does not cause oxidative damage (24).

Although in our study there was no evidence that preconditioning ischemia as well as proton pump inhibitors reduces the value of hydroxyl radicals, due to the overall reduction of all parameters of oxidative damage it can be indicated possible the same scenarios as in the previously described studies.

The process of lipid peroxidation may occur through non-enzymatic and be mediated by reactive oxygen species resulting in the formation of malondialdehyde (MDA). Exposure to high levels of lipid peroxidation products can cause a variety of cellular responses, ranging from acute toxic to the inhibition of cell proliferation (25).

Our results showed that in all groups, there was a decrease in the values of superoxide anion radicals and hydrogen peroxide. How $\mathrm{O}_{2}$ - leads to lipid peroxidation of membranes of endothelial cells, reduction of the levels of these pro-oxidant is in correlation with the lower values of lipid peroxidation (TBARS) (16). Reducing TBARS values can be traced through all the experimental groups, which clearly shows the percentage drop in the value of the point R7 in relation to point of stabilization. The difference between the values at the end of reperfusion, and the basal value at the beginning of the experiment did not differ statistically in a group where we executed ischemic preconditioning and preconditioning with pantoprazole. This might be a sign that in these groups after a large percentage drop during reperfusion period at the end of reperfusion established that lipid peroxidation and there were no deferens between R7 and S (Table 1, Figure 1).

In the group where omeprazole was applied we found that there has been a decline in the values in the reperfusion period compared to stabilization for $55.56 \%$. Moreover as in this group came up almost the largest decrease in the concentration of hydrogen peroxide, it can be assumed that lipid peroxidation due to at least because the minimum production of hydroxyl radicals. Hayashi et al. on the model of isolated rat liver showed that omeprazole decreases the values of lipid peroxidation (26) while on indomethacin-induced gastritis in rats demonstrated that administration of omeprazole prevent an increase in TBARS values (27).

\section{CONCLUSION}

Examining a biochemical markers of oxidative damage we did not notice any increased production values of any parameter, according to that we can hypothesize that possible occurrence of reperfusion injury after ischemia and PPIs preconditioning is not mediated by this mechanism.
Due to the very difficult and controversial application of ischemic preconditioning in clinical practice, the results of this study suggest that in the future drugs called proton pump inhibitors can contribute to the prevention of myocardial damage following ischemia, especially because these days this group of drugs is one of the most prescribing.

\section{Acknowledgment}

This study is supported by Junior Project (JP 3/11) of Faculty of Medical Sciences, University of Kragujevac, Kragujevac, Serbia.

\section{REFERENCES}

1. Przyklenk, K., \& Kloner, R. A. (1998). Ischemic preconditioning: exploring the paradox. Prog Cardiovasc Dis, 40(6), 517-547.

2. Ara, J., Fekete, S., Frank, M., Golden, J. A., Pleasure, D., \& Valencia, I. (2011). Hypoxic-preconditioning induces neuroprotection against hypoxia-ischemia in newborn piglet brain. Neurobiol Dis, 43(2), 473-485.

3. Cantagrel, S., Krier, C., Ducrocq, S., Bodard, S., Payen, V., Laugier, J., Chalon, S. (2003). Hypoxic preconditioning reduces apoptosis in a rat model of immature brain hypoxia-ischaemia. Neurosci Lett, 347(2), 106-110.

4. Altug, S., Demiryurek, A. T., Kane, K. A., \& Kanzik, I. (2000). Evidence for the involvement of peroxynitrite in ischaemic preconditioning in rat isolated hearts. Br J Pharmacol, 130(1), 125-131.

5. Verma, S., Maitland, A., Weisel, R. D., Li, S. H., Fedak, P. W., Pomroy, N. C., Rao, V. (2002). Hyperglycemia exaggerates ischemia-reperfusion-induced cardiomyocyte injury: reversal with endothelin antagonism. J Thorac Cardiovasc Surg, 123(6), 1120-1124.

6. Yellon, D. M., \& Hausenloy, D. J. (2007). Myocardial reperfusion injury. N Engl J Med, 357(11), 1121-1135.

7. Gomes, O. M., Magalhaes Mde, M., \& Abrantes, R. D. (2010). Myocardium functional recovery protection by omeprazole after ischemia-reperfusion in isolated rat hearts. Rev Bras Cir Cardiovasc, 25(3), 388-392.

8. Gomes, O. M., Magalhaes Mde, M., Abrantes, R. D., \& Kallas, E. (2011). Pantoprazole provides myocardial protection similar to ischemic preconditioning: experimental study of isolated hearts of rats. Rev Bras Cir Cardiovasc, 26(3), 433-439.

9. Jeremic, N., Petkovic, A., Srejovic, I., Zivkovic, V., Djuric, D., \& Jakovljevic, V. (2015). Effects of ischemia and omeprazole preconditioning on functional recovery of isolated rat heart. Rev Bras Cir Cardiovasc, 30(2), 266-275.

10. Ohkawa, H., Ohishi, N., \& Yagi, K. (1979). Assay for lipid peroxides in animal tissues by thiobarbituric acid reaction. Anal Biochem, 95(2), 351-358. 
11. Green, L. C., Wagner, D. A., Glogowski, J., Skipper, P. L., Wishnok, J. S., \& Tannenbaum, S. R. (1982). Analysis of nitrate, nitrite, and [15N]nitrate in biological fluids. Anal Biochem, 126(1), 131-138.

12. C Auclair, E Voisin. (1985). Nitroblue tetrazolium reduction Vol. 123. Handbook of methods for oxygen radical research (pp. 123-132).

13. Pick, E., \& Keisari, Y. (1980). A simple colorimetric method for the measurement of hydrogen peroxide produced by cells in culture. J Immunol Methods, 38(12), 161-170.

14. Goswami, S. K., Maulik, N., \& Das, D. K. (2007). Ischemia-reperfusion and cardioprotection: a delicate bal$\overline{\text { ance between reactive oxygen species generation and }}$ redox homeostasis. Ann Med, 39(4), 275-289.

15. Kurzelewski, M., Czarnowska, E., \& Beresewicz, A. (2005). Superoxide- and nitric oxide-derived species mediate endothelial dysfunction, endothelial glycocalyx disruption, and enhanced neutrophil adhesion in the post-ischemic guinea-pig heart. J Physiol Pharmacol, 56(2), 163-178.

16. Raedschelders, K., Ansley, D. M., \& Chen, D. D. (2012). The cellular and molecular origin of reactive oxygen species generation during myocardial ischemia and reperfusion. Pharmacol Ther, 133(2), 230-255.

17. Nonami, Y. (1997). The role of nitric oxide in cardiac ischemia-reperfusion injury. Jpn Circ J, 61(2), 119-132.

18. Hess, M. L., \& Manson, N. H. (1984). Molecular oxygen: friend and foe. The role of the oxygen free radical system in the calcium paradox, the oxygen paradox and ischemia/ reperfusion injury. J Mol Cell Cardiol, 16(11), 969-985.

19. Pagliaro, P., \& Penna, C. (2015). Redox signalling and cardioprotection: translatability and mechanism. Br J Pharmacol, 172(8), 1974-1995.
20. Wandall, J. H. (1992). Effects of omeprazole on neutrophil chemotaxis, super oxide production, degranulation, and translocation of cytochrome b-245. Gut, 33(5), 617-621.

21. Hackert, T., Tudor, S., Felix, K., Dovshanskiy, D., Hartwig, W., Simon, W. A., \& Werner, J. (2010). Effects of pantoprazole in experimental acute pancreatitis. Life Sci, 87(17-18), 551-557.

22. Simon, W. A., Sturm, E., Hartmann, H. J., \& Weser, U. (2006). Hydroxyl radical scavenging reactivity of proton pump inhibitors. Biochem Pharmacol, 71(9), 1337-1341.

23. Biswas, K., Bandyopadhyay, U., Chattopadhyay, I., Varadaraj, A., Ali, E., \& Banerjee, R. K. (2003). A novel antioxidant and antiapoptotic role of omeprazole to block gastric ulcer through scavenging of hydroxyl radical. J Biol Chem, 278(13), 10993-11001.

24. Gozal, Y., Chevion, M., Elami, A., Berenshtein, E., Kitrossky, N., \& Drenger, B. (2005). Ischaemic preconditioning but not isoflurane prevents post-ischaemic production of hydroxyl radicals in a canine model of ischaemia-reperfusion. Eur J Anaesthesiol, 22(1), 49-55.

25. Doucet, A. (1997). H+, K(+)-ATPASE in the kidney: localization and function in the nephron. Exp Nephrol, 5(4), 271-276.

26. Hayashi, H., Shimamoto, K., Taniai, E., Ishii, Y., Morita, R., Suzuki, K., Mitsumori, K. (2012). Liver tumor promoting effect of omeprazole in rats and its possible mechanism of action. J Toxicol Sci, 37(3), 491-501.

27. Petronilho, F., Araujo, J. H., Steckert, A. V., Rezin, G. T., Ferreira, G. K., Roesler, R., Streck, E. L. (2009). Effect of a gastrin-releasing peptide receptor antagonist and a proton pump inhibitor association in an animal model of gastritis. Peptides, 30(8), 1460-1465. 